\title{
An Assessment of the Environmental Impacts of Catchment Management on the Status of Pong Wetland in District Kangra of Himachal Pradesh
}

\author{
Nancy Loria ${ }^{1 *}$, K. S. Verma ${ }^{2}$ and S. K. Bhardwaj ${ }^{1}$ \\ ${ }^{1}$ Dept. of Environmental Science Dr. Y. S. Parmar University of Horticulture and Forestry, Nauni, \\ Solan, H.P. (173 230), India \\ ${ }^{2}$ Dr. Y. S. Parmar University of Horticulture and Forestry, Nauni, Solan, H.P. (173 230), India
}

\section{Article History}

Manuscript No. AR1258

Received in $31^{\text {st }}$ January, 2015

Received in revised form $24^{\text {th }}$ September, 2015

Accepted in final form $6^{\text {th }}$ October, 2015

\section{Correspondence to}

*E-mail: lorianancy@gmail.com

\section{Keywords}

Catchment, land use, nutrients, heavy metals, Pong wetland

\begin{abstract}
The study on the environmental impacts of catchment management on the status of Pong wetland was conducted during the year 2011-12 in the immediate catchment of Pong reservoir. Four main tributaries viz., Buhal, Dehar, Gaj and Banerwere selected to determine spatial trends in nutrient concentrations and to relate these trends to different land use systems in the catchment. Each tributary was divided into four sites of $5 \mathrm{~km}$ each. Site which does not form the catchment of Pong reservoir was excluded. Nutrient concentrations at most of the sites within the catchment were found within the permissible limits. However, no spatial trend was observed along a longitudinal gradient in the nutrient concentrations of tributaries taken under study. Spatial distribution of land use system in the catchment of wetland corroborated that catchment under study covered maximum area under forest land use followed by cultivated land and barren land. Three representative samples of silt at different locations were collected from the lake at the point of their entry into the lake and were used to analyze for certain heavy metals like $\mathrm{Cd}, \mathrm{Fe}, \mathrm{Cu}, \mathrm{Zn}$. Silt characteristics of lake were showed that lake sediments contain heavy metals but ranged within the permissible limits. However, increase in their concentration in near future may cause changes in the physico-chemical composition of the lake water. Improved management and maintenance of catchment land use systems are crucial and there is a need to conserve and preserve these existing wetlands to maintain and improve the ecological balance.
\end{abstract}

\section{Introduction}

The Pong wetland located in the Kangra District of Himachal Pradesh has been declared 'Ramsar site-wetland of international importance' and formed by the construction of Pong Dam during 1975 across the Beas River. It is one of the largest man-made wetlands of the northern India. State owned; the Beas Bhakhra Management Board (BBMB) controls the reservoir, and the H.P. State Forest Department, the catchment area. Fishing and cultivation along the shoreline are a source of some disturbance and the most serious threat comes from the exploitation of catchment resources by humans. The losses of wetlands caused by agriculture are largely attributed to the drainage and conversion of wetlands to croplands, increased rates of sedimentation due to soil loss within catchments, reduced stream flow from dam building and abstraction, the spread of alien invasive plant species and poor management of burning and grazing. Draining and converting wetlands to croplands has been well demonstrated to have high impacts on wetland characteristics and functioning (Willrich and Smith, 1970; Kotze and Breen, 2000). The wetland's ability to attenuate and purify storm flow is greatly reduced, with subsequent impact on downstream water users such as humans or other aquatic systems. The complete loss of wetland habitat is associated with the conversion to croplands. Drainage can also negatively affect dry season water flow and supply (Roggeri, 1995). This can have serious effects on downstream biota and on water quality through the concentration of pollutants. The destruction of wetlands and riparian zones increases sediment movement via streams, with the sediment diminishing habitat diversity and destroying ecological corridors in the landscape. The streams in connected wetlands deposit increased sediment loads, which results in severe environmental damage (Junk, 2002). Recognizing that wetland is strongly influenced by the 
management of their catchments from which it receive water, the study was conducted with the objective to determine spatial trends in nutrient concentrations of streams connected to wetland and to relate these trends to different land use systems in the catchment.

\section{Materials and Methods}

\subsection{Study site}

The Pong dam reservoir extends between latitudes $31^{\circ} 49^{\prime}$ to $32^{\circ} 14^{\prime}$ North and longitudes $75^{\circ} 53^{\prime}$ to $76^{\circ} 17^{\prime}$ East. The altitude varies between $335-435 \mathrm{~m}$ msl. The climate of the Pong Dam Lake is typical of the northern India i.e. sub-tropical. Predominant land use systems practiced by the catchment inhabitants are agriculture, pasture and forestry. Fishing and cultivation are two main shoreline activities affecting the health of aquatic ecosystem.

\subsection{Method of data collection}

For conducting present study, sampling for water was done during the month of October and November in the year 2011 from the immediate catchment of Pong reservoir. Further analysis of the water samples was carried out in the laboratory of Department of Environmental Science, Dr. Y.S. Parmar University of Horticulture and Forestry, Nauni, Solan (Himachal Pradesh, India) during the year 2012. The actual study area comprised of catchment upto $20 \mathrm{~km}$ distance from the reservoir. The four main tributaries viz., Buhal, Dehar, Gaj and Baner those directly drains into Pong reservoir were selected for the study. Each tributary (upto $20 \mathrm{~km}$ from the reservoir) was divided into 4 sites such that each covers $5 \mathrm{~km}$ i.e. $\mathrm{S}_{1}(0-5 \mathrm{~km}), \mathrm{S}_{2}(5-10 \mathrm{~km}), \mathrm{S}_{3}(10-15 \mathrm{~km})$ and $\mathrm{S}_{4}(15-20$ $\mathrm{km})$. In this way number of sites formed for water sampling were 15 as one site of Buhal tributary was excluded because it does not form the catchment of Pong reservoir. Random sampling of water quality was conducted at these sites along a longitudinal gradient in the four main tributaries. Collected water samples were analysed for $\mathrm{pH}$ (glass electrode method), electrical conductivity (glass electrode method), suspended and dissolved solids (gravimetric method) and other parameters like potassium and calcium were estimated using flame photometer. Magnesium, sodium, chlorides, sulphates and phosphates were estimated spectrophotometrically by using Spectroquant Pharo 300 (APHA, 1998).

Data regarding status of catchment upto $20 \mathrm{~km}$ distance from the Pong reservoir was obtained from the Department of Agriculture. Field survey 2007-2008 conducted by Dept. of Agriculture (2009) in their District Agriculture Plan (DAP):Kangra, H.P., Vol. IV has shown block wise land utilization pattern in the district Kangra. The data obtained from such survey was used to have the estimate of land use pattern covered under study area within different blocks (Table 1). Blocks which were coming within $20 \mathrm{~km}$ aerial stretch from Pong Wetland were covered under study. The rough estimate of the study area within different blocks was made using the district map scale $(1 \mathrm{~cm}=1.2 \mathrm{~km})$. Then the percentage of study area from total geographical area within different blocks was calculated and further land use pattern within different blocks on the basis of percentage given in DAP Plan was calculated.

Three representative samples of silt of different locations were collected from the lake at the point of their entry into the lake. After collection, samples were air dried in shade, ground with wooden pestle mortar, passed through $2 \mathrm{~mm}$ sieve and stored in cloth bags. These sieved samples were then digested using method as prescribed by Saison et al. (2004) to estimate certain heavy metals like $\mathrm{Cd}, \mathrm{Fe}, \mathrm{Cu}$, and $\mathrm{Zn}$ and then analysed in Inductively Coupled Plasma Analyzer (ICPA).

\section{Results and Discussion}

\subsection{Spatial trends in nutrient concentrations}

Data presented in Table 2 revealed that $S_{1}$ site of Buhal tributary showed the maximum values for total suspended solids (TSS), magnesium $(\mathrm{Mg})$, chloride $\left(\mathrm{Cl}^{-}\right)$and sulphate $\left(\mathrm{SO}_{4}{ }^{2-}\right) . \mathrm{S}_{2}$ Site showed maximum values for total dissolved solids (TDS) and potassium (K). $\mathrm{S}_{3}$ site of Buhal tributary showed highest values for $\mathrm{pH}$, electrical conductivity (EC), $\mathrm{Ca}, \mathrm{Na}$ and phosphate $\left(\mathrm{PO}_{4}^{2-}\right)$.

Data presented in Table 3 revealed that $\mathrm{S}_{1}$ site of Dehar tributary showed the maximum values for $\mathrm{pH}$, TSS and phosphate. $\mathrm{S}_{2}$ site showed maximum values for $\mathrm{K}$ and $\mathrm{Ca}$. $\mathrm{S}_{3}$ site showed highest value for electrical conductivity. $\mathrm{S}_{4}$ site of this tributary resulted in maximum values for TDS, Mg, Na, chloride and sulphate.

Data presented in Table 4 revealed that $S_{1}$ site of Gaj tributary has greater $\mathrm{pH}, \mathrm{TSS}, \mathrm{Ca}, \mathrm{Mg}$ and chloride values in comparison to other nutrients. $\mathrm{S}_{2}$ site showed maximum values for TDS and sulphate. $\mathrm{S}_{3}$ site showed highest value for $\mathrm{EC}, \mathrm{K}$ and $\mathrm{Na}$. $\mathrm{S}_{4}$ site of this tributary resulted in maximum values for phosphate.

Data presented in Table 5 revealed that $S_{1}$ site of Baner tributary showed the maximum values for TSS, $\mathrm{Ca}$ and phosphate. $\mathrm{S}_{2}$ Site showed maximum values for $\mathrm{pH}$ and $\mathrm{Na}$. $\mathrm{S}_{3}$ site showed highest values for chloride and sulphate. $\mathrm{S}_{4}$ site of this tributary resulted in maximum values for $\mathrm{EC}, \mathrm{TDS}, \mathrm{K}$ and $\mathrm{Mg}$.

The tributaries of pong wetland revealed in the results that $\mathrm{pH}$ for all sites was above 7 and $\mathrm{pH}$ values generally increased from the neutral to alkaline range. Electrical conductivity was due to the presence of salts in the tributaries. In Kawar Lake, India, a similar range of conductivity has been recorded, George (1962). The total dissolved solidsin tributaries were 


\begin{tabular}{|c|c|c|c|c|c|c|c|c|}
\hline \multicolumn{2}{|l|}{ Blocks } & \multirow{2}{*}{$\begin{array}{l}\text { Fateh- } \\
\text { pur } \\
75.24\end{array}$} & \multirow{2}{*}{$\begin{array}{c}\text { Nurpur } \\
140.94\end{array}$} & \multirow{2}{*}{$\begin{array}{l}\text { Nagrota } \\
\text { Surian } \\
372.68\end{array}$} & \multirow{2}{*}{$\begin{array}{l}\text { Rait } \\
148.8\end{array}$} & \multirow{2}{*}{$\begin{array}{c}\text { Kangra } \\
159.23\end{array}$} & \multirow{2}{*}{$\begin{array}{l}\text { Dehra } \\
\text { Gopipur } \\
34.15\end{array}$} & \multirow{2}{*}{$\begin{array}{l}\text { Total } \\
931.04\end{array}$} \\
\hline Total geographical area & & & & & & & & \\
\hline \multirow[t]{3}{*}{ Forests } & Productive & 10.46 & 47.05 & 140.93 & 0 & 71.86 & 6.55 & 276.85 \\
\hline & Degraded & 3.30 & 0 & 0 & 37.35 & 0 & 0 & 40.65 \\
\hline & Total & 13.76 & 47.05 & 140.93 & 37.35 & 71.86 & 6.55 & 317.5 \\
\hline Barren land (Rocky) & & 0.77 & 12.54 & 20.21 & 73.05 & 7.12 & 10.68 & 124.37 \\
\hline \multirow{3}{*}{$\begin{array}{l}\text { Land put to } \\
\text { non-agricultural uses }\end{array}$} & Buildings & 1.78 & 11.57 & 27.23 & 2.31 & 14.49 & 3.81 & 61.19 \\
\hline & Roads/paths/channels & 5.79 & 0 & 0 & 1.73 & 0 & 0 & 7.53 \\
\hline & total & 7.57 & 11.57 & 27.23 & 4.04 & 14.49 & 3.81 & 68.72 \\
\hline \multirow[t]{3}{*}{ Culturable waste } & Weed/bush infested & 6.82 & 3.17 & 18.03 & 2.45 & 3.17 & 0.85 & 34.49 \\
\hline & $\begin{array}{l}\text { Area prone to animal } \\
\text { menace }\end{array}$ & 6.55 & 3.49 & 0 & 1.15 & 0 & 0 & 11.2 \\
\hline & Total & 13.37 & 6.66 & 18.03 & 3.60 & 3.17 & 0.85 & 45.69 \\
\hline \multirow{3}{*}{$\begin{array}{l}\text { Permanent pastures and } \\
\text { other grazing lands }\end{array}$} & Productive & 5.85 & 2.3 & 13.46 & 0.0020 & 12.51 & 3.15 & 37.29 \\
\hline & Degraded & 4.24 & 0 & 0 & 0.0052 & 0 & 0 & 4.25 \\
\hline & total & 10.09 & 2.3 & 13.46 & 0.0072 & 12.51 & 3.15 & 41.54 \\
\hline \multicolumn{2}{|c|}{ Miscellaneous trees and groves } & 3.48 & 0.52 & 19.16 & 1.43 & 8.55 & 1.34 & 34.48 \\
\hline \multirow[t]{3}{*}{ Fallow land } & Current fallow & 0.22 & 2.09 & 13.44 & 0.22 & 1.62 & 0.98 & 18.57 \\
\hline & Other fallow & 1.23 & 0 & 23.46 & 0.57 & 0 & 0 & 25.26 \\
\hline & Total & 1.45 & 2.09 & 36.9 & 0.79 & 1.62 & 0.98 & 43.83 \\
\hline Cultivated land & & 24.73 & 58.17 & 96.76 & 27.48 & 39.90 & 6.81 & 253.85 \\
\hline
\end{tabular}

Table 2: Spatial trends in nutrient concentrations for Buhal tributary

\begin{tabular}{|c|c|c|c|c|c|c|c|c|c|c|c|}
\hline Parameters & $\mathrm{pH}$ & $\begin{array}{c}\mathrm{EC} \\
\left(\mathrm{mmhos} \mathrm{cm}^{-1}\right)\end{array}$ & $\begin{array}{c}\text { TDS } \\
\left(\mathrm{mg} \mathrm{l}^{-1}\right)\end{array}$ & $\begin{array}{c}\text { TSS } \\
\left(\mathrm{mg} \mathrm{l}^{-1}\right)\end{array}$ & $\begin{array}{c}\mathrm{K} \\
\left(\mathrm{mg} \mathrm{l}^{-1}\right)\end{array}$ & $\begin{array}{c}\mathrm{Ca} \\
\left(\mathrm{mg} \mathrm{l}^{-1}\right)\end{array}$ & $\begin{array}{c}\mathrm{Mg} \\
\left(\mathrm{mg} \mathrm{l}^{-1}\right)\end{array}$ & $\begin{array}{c}\mathrm{Na} \\
\left(\mathrm{mg} \mathrm{l}^{-1}\right)\end{array}$ & $\begin{array}{c}\mathrm{Cl}- \\
\left(\mathrm{mg} \mathrm{l}^{-1}\right)\end{array}$ & $\begin{array}{l}\mathrm{SO}_{4}^{2-} \\
\left(\mathrm{mg} \mathrm{l}^{-1}\right)\end{array}$ & $\begin{array}{l}\mathrm{PO}_{4}^{2-} \\
\left(\mathrm{mg} \mathrm{l}^{-1}\right)\end{array}$ \\
\hline \multicolumn{12}{|l|}{ Sites } \\
\hline$\left.\overline{\mathrm{S}_{1}(0-5} \mathrm{km}\right)$ & 7.02 & 0.243 & 139.7 & 19.6 & 11.4 & 41.3 & 12.9 & 98.4 & 5.4 & 5 & 0.9 \\
\hline $\mathrm{S}^{2}(5-10 \mathrm{~km})$ & 7.09 & 0.258 & 142.1 & 19 & 12.1 & 50.9 & 11.5 & 143 & 3.5 & 4 & 4.8 \\
\hline $\mathrm{S}_{3}(10-15 \mathrm{~km})$ & 7.13 & 0.324 & 141.5 & 17.8 & 5.6 & 58.2 & 11.6 & 273 & 1.9 & 3 & 9.5 \\
\hline Parameters & $\mathrm{pH}$ & $\begin{array}{c}\text { EC } \\
\left(\mathrm{mmhos} \mathrm{cm}^{-1}\right)\end{array}$ & $\begin{array}{c}\text { TDS } \\
\left(\mathrm{mg} \mathrm{l}^{-1}\right)\end{array}$ & $\begin{array}{c}\mathrm{TSS} \\
\left(\mathrm{mg} \mathrm{l}^{-1}\right)\end{array}$ & $\begin{array}{c}\mathrm{K} \\
\left(\mathrm{mg} \mathrm{l}^{-1}\right) \\
\end{array}$ & $\begin{array}{c}\mathrm{Ca} \\
\left(\mathrm{mg} \mathrm{l}^{-1}\right)\end{array}$ & $\begin{array}{c}\mathrm{Mg} \\
\left(\mathrm{mg} \mathrm{l}^{-1}\right)\end{array}$ & $\begin{array}{c}\mathrm{Na} \\
\left(\mathrm{mg} \mathrm{l}^{-1}\right)\end{array}$ & $\begin{array}{c}\mathrm{Cl}- \\
\left(\mathrm{mg} \mathrm{l}^{-1}\right)\end{array}$ & $\begin{array}{c}\mathrm{SO}_{4}^{2-} \\
\left(\mathrm{mg} \mathrm{l}^{-1}\right) \\
\end{array}$ & $\begin{array}{c}\mathrm{PO}_{4}^{2-} \\
\left(\mathrm{mg} \mathrm{l}^{-1}\right)\end{array}$ \\
\hline \multicolumn{12}{|l|}{ Sites } \\
\hline $\mathrm{S}_{1}(0-5 \mathrm{~km})$ & 7.35 & 0.231 & 153.4 & 18.8 & 7.5 & 56 & 9.4 & 4.3 & 10 & 3 & 18.1 \\
\hline $\mathrm{S}_{2}(5-10 \mathrm{~km})$ & 7.19 & 0.402 & 157 & 17.4 & 33.8 & 57.1 & 10.5 & 44.6 & 5.7 & 5 & 1.2 \\
\hline $\mathrm{S}_{3}(10-15 \mathrm{~km})$ & 7.14 & 0.577 & 112.8 & 14.4 & 4.3 & 34.2 & 11.7 & 107 & 8 & 6 & 0.7 \\
\hline $\mathrm{S}_{4}(15-20 \mathrm{~km})$ & 7.03 & 0.522 & 158.2 & 16.6 & 12.2 & 40.9 & 12.6 & 223 & 14.5 & 143 & 17.7 \\
\hline
\end{tabular}

within prescribed limits for irrigation. This may be due to less agricultural and residential runoff and leaching of soil contaminants. As such no trend in $\mathrm{pH}, \mathrm{EC}$ and TDS was observed along a longitudinal gradient during the study. The total suspended solids increased with the increase in turbidity. TSS has shown increasing trend downstream with its highest 


\begin{tabular}{lccccccccccc}
\hline \multicolumn{10}{l}{ Table 4: Spatial trends in nutrient concentrations for Gaj tributary } \\
\hline Parameters & $\mathrm{pH}$ & $\begin{array}{c}\mathrm{EC} \\
\left(\mathrm{mmho} \mathrm{cm}^{-1}\right)\end{array}$ & $\begin{array}{c}\mathrm{TDS} \\
\left(\mathrm{mg} \mathrm{l}^{-1}\right)\end{array}$ & $\begin{array}{c}\mathrm{TSS} \\
\left(\mathrm{mg} \mathrm{l}^{-1}\right)\end{array}$ & $\begin{array}{c}\mathrm{K} \\
\left(\mathrm{mg} \mathrm{l}^{-1}\right)\end{array}$ & $\begin{array}{c}\mathrm{Ca} \\
\left(\mathrm{mg} \mathrm{l}^{-1}\right)\end{array}$ & $\begin{array}{c}\mathrm{Mg} \\
\left(\mathrm{mg} \mathrm{l}^{-1}\right)\end{array}$ & $\begin{array}{c}\mathrm{Na} \\
\left(\mathrm{mg} \mathrm{l}^{-1}\right)\end{array}$ & $\begin{array}{c}\mathrm{Cl}- \\
\left(\mathrm{mg} \mathrm{l}^{-1}\right)\end{array}$ & $\begin{array}{c}\mathrm{SO}_{4}^{2-} \\
\left(\mathrm{mg} \mathrm{l}^{-1}\right)\end{array}$ & $\begin{array}{c}\mathrm{PO}_{4}^{2-} \\
\left(\mathrm{mg} \mathrm{l}^{-1}\right)\end{array}$ \\
\hline Sites & & & & & & & & & & & \\
$\mathrm{S}_{1}(0-5 \mathrm{~km})$ & 7.28 & 0.330 & 149.8 & 19.4 & 1.58 & 61.2 & 11.2 & 7.6 & 9.2 & 8 & 5.6 \\
$\mathrm{~S}_{2}(5-10 \mathrm{~km})$ & 7.09 & 0.452 & 172.5 & 18.2 & 1.34 & 45.1 & 9.7 & 6.7 & 1.5 & 21 & 10.1 \\
$\mathrm{~S}_{3}(10-15 \mathrm{~km})$ & 7.15 & 0.491 & 101.1 & 15.6 & 12.14 & 57.2 & 10.4 & 148.8 & 8.5 & 4 & 14 \\
$\mathrm{~S}_{4}(15-20 \mathrm{~km})$ & 7.26 & 0.396 & 140.3 & 14.2 & 4 & 52.9 & 9.9 & 36.9 & 3.6 & 5 & 14.7 \\
\hline
\end{tabular}

value at Site $S_{1}$ and lowest value at Site $S_{4}$ (Table 2-5).

The presence of potassium indicated that the tributaries were influenced by human activities. Its occurrence in water may be attributed to potash fertilizers and animal waste. High $\mathrm{Ca}$ and $\mathrm{Mg}$ content contributed to the total hardness of water. These occurs in water in carbonate or bicarbonates form. The tributaries remained unaffected by $\mathrm{Mg}$ and $\mathrm{Ca}$ concentration as these ranged within the limits prescribed for irrigation. Sodium presence indicated that the tributaries were influenced by human activities. Sodium found its way into tributaries from road salt, fertilizers, and human and animal waste. Chloride may have occurred in tributary due to animal waste, potash fertilizer and drainage from road-salting chemicals. Sulfate in the tributaries was primarily related to the type of minerals in the catchment and activities that burn coal, release sulfur compounds into the atmosphere which are into lake through tributaries. In particular, the increased mining activity along the length of tributaries most likely impacts on the lake, as indicated by the increased sulphate concentrations measured at Site 4 of Dehar tributary (Table 3) and Site 3 of Baner tributary (Table 5). Increased sulphate concentrations are commonly associated with mining activity as a result of the exposure of pyrite to oxygen and water (Bullock and Bell, 1997). In the present studies, highest amount of phosphates was recorded in the area where agricultural runoff and activities like bathing and washing clothes occurred in the tributary bank. Increased amount of phosphates and coliform contamination in streams closer to anthropogenic activities was also reported by Karthick and Ramachandra (2007). No spatial trend was observed along a longitudinal gradient in the nutrient concentrations of tributaries taken under study (Table 2-5).

\subsection{Spatial distribution of land use catchment}

The catchment of wetland under current study was spread over an area of $931.04 \mathrm{~km} 2$ which was $7.41 \%$ of the total catchment of Pong reservoir. Out of $931.04 \mathrm{~km} \mathrm{2,} \mathrm{maximum}$ area i.e. $34 \%$ was covered under forests followed by cultivated land $27 \%$, barren land $13 \%$, land put to non-agricultural uses $7 \%$, culturable waste $5 \%$, permanent pasture and other grazing lands 5\%, fallow land 5\% and least area under miscellaneous trees and groves 4\% (Figure 1).

\subsection{Status of Heavy metal in lake silt}

Heavy metal viz., $\mathrm{Fe}, \mathrm{Cu}, \mathrm{Cd}$ and $\mathrm{Zn}$ concentration in lake silt from different stations differed significantly (Table 6). Fe in lake silt ranged from $2705.6 \mathrm{mg} \mathrm{kg}^{-1}$ to $4076.5 \mathrm{mg} \mathrm{kg}^{-1}$

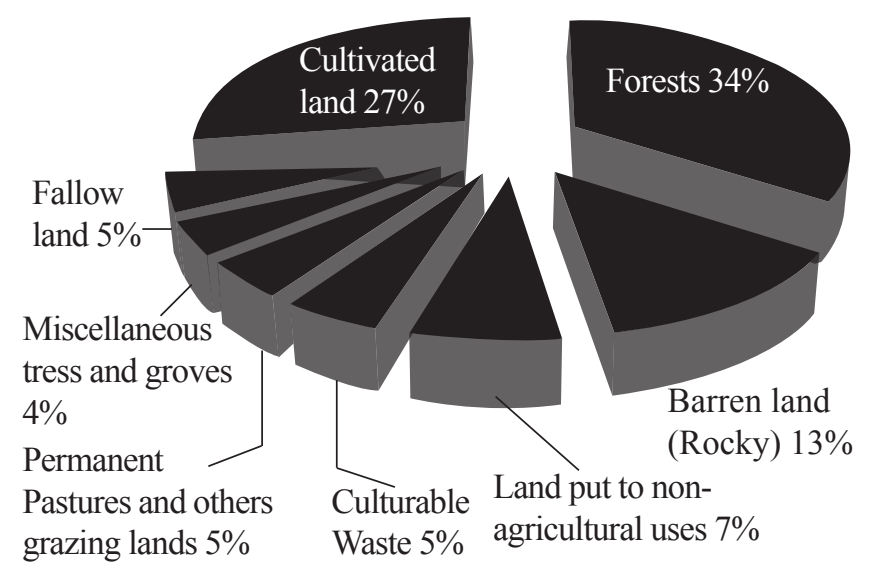

Figure 1: Spawtial distribution of land use system in the study area (\%)

\begin{tabular}{lcccccccccccc}
\hline \multicolumn{10}{l}{ Table 5: Spatial trends in nutrient concentrations for Baner tributary } \\
\hline Parameters & $\mathrm{pH}$ & $\begin{array}{c}\mathrm{EC} \\
\left(\mathrm{mmhos} \mathrm{cm}^{-1}\right)\end{array}$ & $\begin{array}{c}\mathrm{TDS} \\
\left(\mathrm{mg} \mathrm{l}^{-1}\right)\end{array}$ & $\begin{array}{c}\mathrm{TSS} \\
\left(\mathrm{mg} \mathrm{l}^{-1}\right)\end{array}$ & $\begin{array}{c}\mathrm{K} \\
\left(\mathrm{mg} \mathrm{l}^{-1}\right)\end{array}$ & $\begin{array}{c}\mathrm{Ca} \\
\left(\mathrm{mg} \mathrm{l}^{-1}\right)\end{array}$ & $\begin{array}{c}\mathrm{Mg} \\
\left(\mathrm{mg} \mathrm{l}^{-1}\right)\end{array}$ & $\begin{array}{c}\mathrm{Na} \\
\left(\mathrm{mg} \mathrm{l}^{-1}\right)\end{array}$ & $\begin{array}{c}\mathrm{Cl}- \\
\left(\mathrm{mg} \mathrm{l}^{-1}\right)\end{array}$ & $\begin{array}{c}\mathrm{SO}_{4}^{2-} \\
\left(\mathrm{mg} \mathrm{l}^{-1}\right)\end{array}$ & $\begin{array}{c}\mathrm{PO}_{4}^{2-} \\
\left(\mathrm{mg} \mathrm{l}^{-1}\right)\end{array}$ \\
\hline Sites & & & & & & & & & & & \\
$\mathrm{S}_{1}(0-5 \mathrm{~km})$ & 7.45 & 0.174 & 97.4 & 17 & 1.49 & 43.1 & 9.6 & 9.2 & 5 & 21 & 19.5 \\
$\mathrm{~S}_{2}(5-10 \mathrm{~km})$ & 7.56 & 0.269 & 108.6 & 13.2 & 1.03 & 15 & 9.9 & 14.1 & 11 & 16 & 15.6 \\
$\mathrm{~S}_{3}(10-15 \mathrm{~km})$ & 7.11 & 0.107 & 66.7 & 13.8 & 1.58 & 8 & 10.8 & 10.1 & 18 & 246 & 10.1 \\
$\mathrm{~S}_{4}(15-20 \mathrm{~km})$ & 7.3 & 0.349 & 109 & 12 & 7.7 & 10.2 & 12.4 & 8.5 & 6.05 & 5 & 18.2 \\
\hline
\end{tabular}




\begin{tabular}{lcccc}
\hline Table 6: Heavy metal status in silt samples \\
\hline $\begin{array}{l}\text { Sampling } \\
\text { Station }\end{array}$ & $\begin{array}{c}\mathrm{Fe} \\
\left(\mathrm{mg} \mathrm{Kg}^{-1}\right)\end{array}$ & $\begin{array}{c}\mathrm{Cu} \\
\left(\mathrm{mg} \mathrm{Kg}^{-1}\right)\end{array}$ & $\begin{array}{c}\mathrm{Cd} \\
\left(\mathrm{mg} \mathrm{Kg}^{-1}\right)\end{array}$ & $\begin{array}{c}\mathrm{Zn} \\
\left(\mathrm{mg} \mathrm{Kg}^{-1}\right)\end{array}$ \\
\hline Station 1 & 4076.5 & 14.80 & 0.60 & 77.45 \\
Station 2 & 2705.6 & 2.66 & 0.23 & 20.42 \\
Station 3 & 3755 & 10.06 & 0.57 & 54 \\
Mean & 3512.37 & 9.18 & 0.47 & 50.62 \\
\hline
\end{tabular}

with its mean value of $3512 \mathrm{mg} \mathrm{kg}^{-1}$; $\mathrm{Cu}$ ranged from 2.66 $\mathrm{mg} \mathrm{kg}^{-1}$ to $14.80 \mathrm{mg} \mathrm{kg}^{-1}$ with its mean value of $9.18 \mathrm{mg} \mathrm{kg}^{-1}$; Cd ranged from $0.23 \mathrm{mg} \mathrm{kg}^{-1}$ to $0.6 \mathrm{mg} \mathrm{kg}^{-1}$ with its mean value of $0.47 \mathrm{mg} \mathrm{kg}^{-1}$ and $\mathrm{Zn}$ ranged from $20.42 \mathrm{mg} \mathrm{kg}^{-1}$ to $77.45 \mathrm{mg} \mathrm{kg}^{-1}$ with its mean value of $50.62 \mathrm{mg} \mathrm{kg}^{-1}$. All soils and sediments contain some concentration (usually low) of trace and toxicmetals from natural sources. Sediments with low heavy metal concentrations are not necessarily "natural" just because the levels are indeed low. They may represent a mixture of small quantity of pollutants diluted by a large amount of natural sediment with low heavy metal content. (Herut et al., 1993). However, these background levels can vary widely depending on a number of factors such as parent material, sedimentation processes in water bodies and other things. It is usually a result of human activities that levels of metals increase and due to this pollution in soils and sediments can rise to the point where they represent a potential health or ecological risk.

\section{Conclusion}

No spatial trend was observed along a longitudinal gradient in the nutrient concentrations of tributaries taken under study. Heavy metal concentrations in the lake silt were within permissible limits. However, increase in their concentration in near future may cause changes in the physico-chemical composition of the water and finally become unsuitable for human consumption. So there is a need to manage the various land use activities for maintaining the quality of the wetland on sustainable basis.

\section{Acknowledgement}

Appreciation is expressed to the Beas Dam BBMB Talwara for providing the valuable information about Pong Dam and to the Department of Agriculture, Kangra, HP for providing the necessary data regarding block wise land utilization pattern in district Kangra required for successful completion of research work. All staff members of Department of Environmental sciences, UHF, Nauni, Solan are acknowledged for their valuable suggestions and supervision during field collection and laboratory analysis of water quality samples.

\section{References}

APHA (American Public Health Association), 1998. Standard methods for the examination of water and waste water $\left(20^{\text {th }}\right.$ Edn.). American Public Health Association, Washington, D.C., USA, 1220.

Bullock, S.E.T., Bell, F.G., 1997. Some problems associated with past mining at a mine in the Witbank coalfield, South Africa. Environmental Geology 33(1), 61-71.

George, M.G., 1962. Occurrence of permanent algal bloom in a fish tank at Delhi with special reference to factors responsible for its production. Proceedings of the Indian Academy of Sciences 56B, 354-362.

Herut, B., Hornung, H., Krom, M.D., Kress, N., Cohen, Y., 1993. Trace metals in shallow sediments from the Mediterranean coastal region of Israel. Marine Pollution Bulletin 26(12), 675-682.

Junk, W.J., 2002. Long-term environmental trends and the future of tropical wetlands. Environmental Conservation 29(4), 414-435.

Karthick, B., Ramachandra, T.V., 2007. Spatial variation of physico-chemical and hydrological parameters with land use in Venkatapur catchment, Karnataka. Asian Journal of Microbiology, Biotechnology and Environmental Sciences 9(4), 1001-1005.

Kotze, D.C., Breen, C.M., 2000. Wetland-Use: a wetland management decision support system for South African freshwater palustrine wetlands. Department of Environmental Affairs and Tourism, Pretoria, South Africa. Available from http://www.ccwr.ac.za/wetlands/.

Roggeri, H.,1995. Tropical Freshwater Wetlands: a Guide to Current Knowledge and Sustainable Management. Kluwer Acedemic Press, Dordrecht, Netherlands, 349.

Saison, C., Schwartz, C., Morel, J.L., 2004. Hyperaccumulation of metals by Thlaspi caerulescens as affected by root development and $\mathrm{Cd}-\mathrm{Zn} / \mathrm{Ca}-\mathrm{Mg}$ interactions. International Journal of Phytology 6(1), 49-61.

Willrich, T.L., Smith, G.E., 1970. Agricultural Practice and Water Quality.Ames, Iowa State University Press, USA, 415 . 